\title{
Traditional practices : A window for water erosion management in the Argana basin (Western High Atlas - Morocco)
}

\author{
Mohamed Ait Haddou*, Belkacem Kabbachi, Ali Aydda, Youssef Bouchriti, Hicham \\ Gougueni, Mohamed En-Naciry, and Asmae Aichi. \\ Geosciences and Environment Team, Department of Geology, Faculty of Sciences, Ibn Zohr \\ University, Agadir 8106, Morocco.
}

\begin{abstract}
Water and soil are two essential natural resources, which their preservation determines the local and national environmental sustainability. The pollution and erosion processes causing deterioration of these resources, which impacting negativaly the environment and economy development. This research aims to suggest the most straight forward and most appropriate control measures for the basins that are socially and economically acceptable for farmers. By consdering Argana basin as study area, the proposed approach consists, first, to analyze the soil loss map and, then, cconducted semi-structured interviews with local farmers at various locations across the basin. The results indicate that the areas of high and very high deterioration encompass $48 \%$ of the basin's surface. In addition, all of the farmers questioned used agroforestry on their managed sites. The study highlight the importtance of the traditional practices in fighting water erosion risk.
\end{abstract}

\section{Introduction}

In Mediterranean countries, soil erosion due to rainfall and runoff is a wide spread phenomenon. The soil erosion is the most prevalent type of land degradation worldwide [1, 2]. The negative impacts of soil erosion become critical when it surpasses the optimal rate (10.4 t/ha/year) [3]. In 2014, the cost of land degradation in Morocco, including soil erosion and desertification, was estimated to be over 5.01 billion dirhams or $0.54 \%$ of the Gross Domestic Product (GDP) [4]. The Abdelmoumen dam supplies drinking water to the broader Agadir region $\left(9.5 \mathrm{Mm}^{3}\right)$ and irrigation for the Issen periphery (13,000 hectares). This dam is undergoing rapid siltation, with a specific degradation of 646.15 tons $/ \mathrm{km}^{2} /$ year [5]. Watershed management and the management of the implications of soil degradation are gaining a lot of interest from policymakers, especially, for the most degraded regions. In this

\footnotetext{
* Corresponding author: medaithaddou@gmail.com
} 
context, the current study anticipated to provide the simplest and most appropriate method of soil degradation control in the Argana basin (Western High Atlas (WHA), Morocco).

\section{Study area}

The study area, covering an area of about $1300 \mathrm{~km}^{2}$, is a basin in the High Atlas downstream section of the Souss watershed (Figure 1). It is part of the Argana corridor and its surrounding valleys. The Issen River is the largest tributary descending from the southern flank of the western High Atlas of Morocco. In general, the Issen basin is a subject to rainfall instability. In addition, orographic variations influence the distribution of climatic settings in this basin [6]. This basin is considered representative of erosion conditions [7,5]. The succession of the crossing lands has a significant supply of detrital materials as a result. Their imperviousness, high relief, and limited vegetation all impact runoff and material transport in this basin. Because of its physical characteristics, it is prone to rapid and torrential floods.

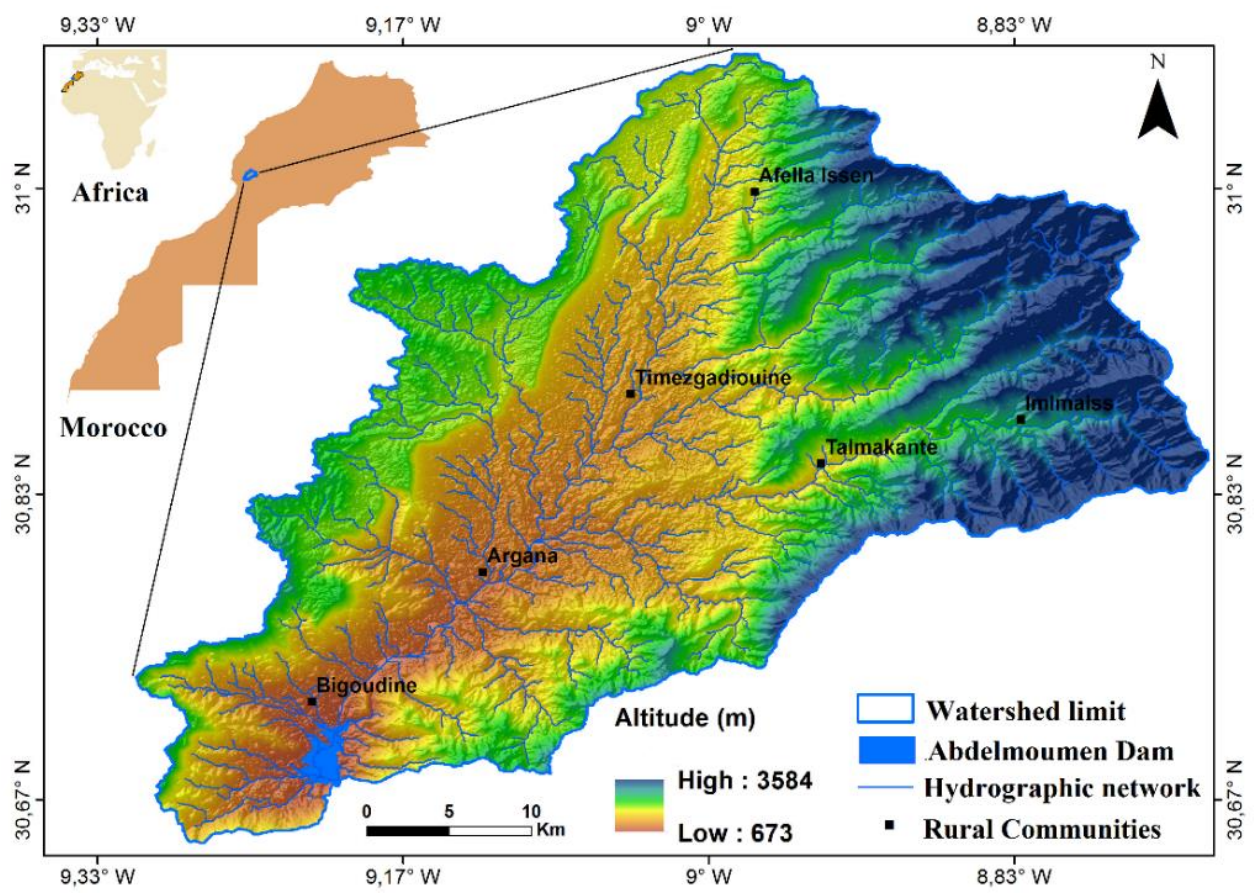

Fig. 1. Study area location.

\section{Methods}

Integrating erosion mapping and erosion risk management into a GIS creates a comprehensive tool for directing land-use decisions. Several studies have conducted this type of research in the High Atlas watersheds [08]. According to Ancy[9], in order to manage the erosion risk, it is necessary to identify the erosion hazard and conservation practices. The conservation practices (land use) should be properly planned according to the potential of dangers (Fig. 2).

In this study, the hazard map was prepared by integraing 5 factors (rain erosivity factor (R), soil erodibility factor (K), slope factor (LS), land cover factor (C), and erosion control practice factor (P)) in GIS platform using the equation of RUSLE model proposed by[10,11]. In fact, the spatial analysis was utilized to find the regions most impacted by erosion and the most susceptible locations in the Argana corridor. The soil loss risk classes were verified based on in-situ observation. In addition, in order to highlight the conservation practices, 
semi-structured interviews were done with 30 farmers across the basin, supplemented by spontaneous interactions with a broader group of farmers. Note of that the field surveys were conducted during the priod 2017-2020.

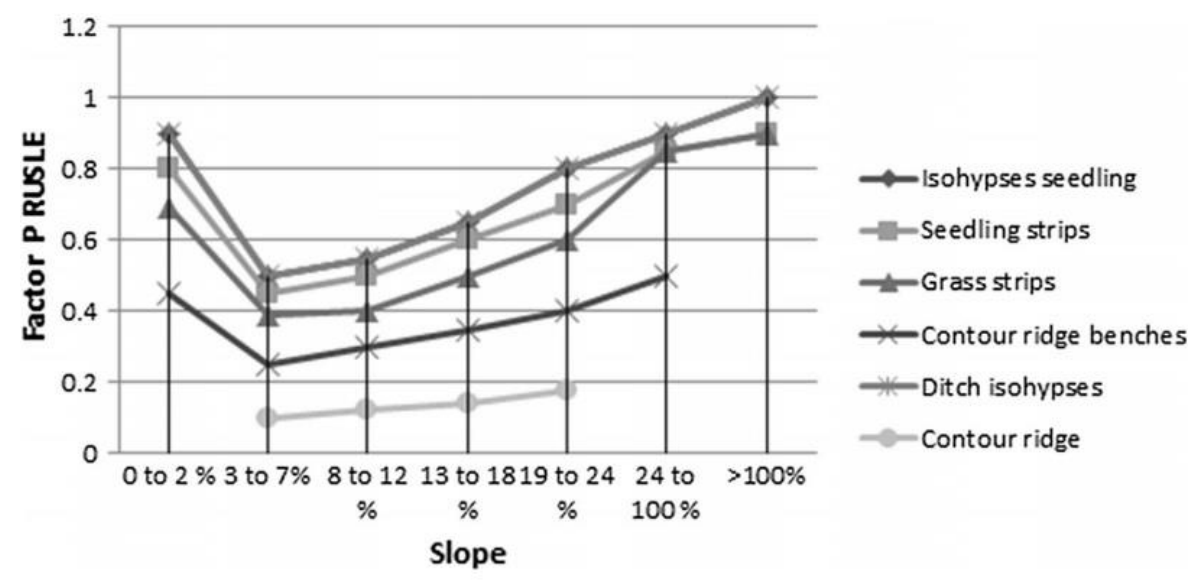

Fig.2.Performance of erosion control methods in relation to the topographic gradient [12].

\section{Results and Discussion}

\subsection{Analysis of the potential erosion map}

The obtained erosion risk map reveals that the most part of the study area is threthend by water erosion phenomenon with three degree of risk: very high risk (risk 3 with loss rate estimated by 100 to $430 \mathrm{t} / \mathrm{ha} / \mathrm{yr}$ ), high risk (risk 2 with loss rate estimated by 20 to 100 t/ha/yr), and moderate risk (risk 1 with loss rate estimated by $0-20 \mathrm{t} / \mathrm{ha} / \mathrm{yr}$ ) (Fig. 3).

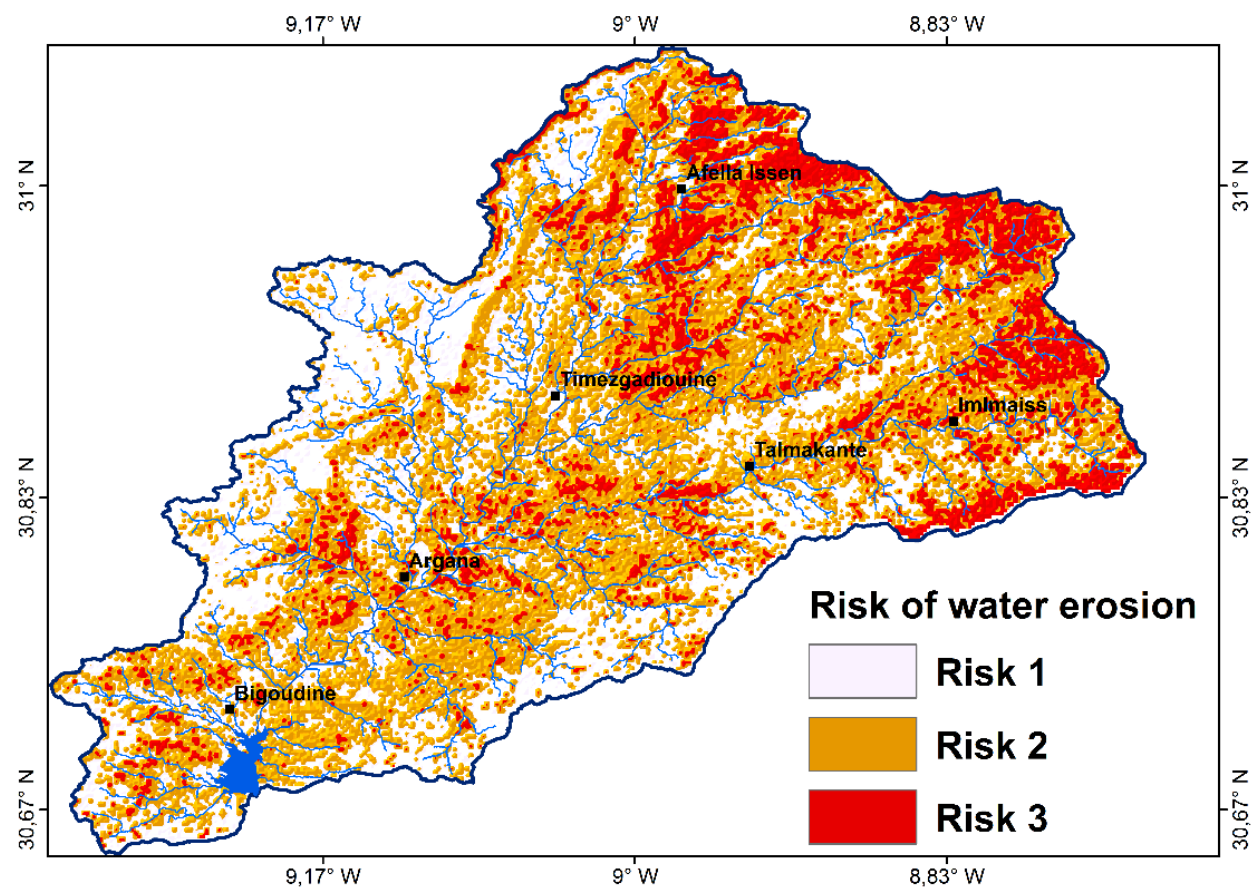

Fig.3. Areas of high risk of water erosion. 
Table 1 lists the characteristics of the water erosion risk weighting in the study area. Therefore, huge areas with agricultural potential are sterilized or in the process of sterilization, particularly in locations with fragile rocks, like in the center of the Argana corridor. Because of the large size of the basin and the number of hot spots involved, the sector situated in the center of the Argana corridor was chosen as a priority intervention target.

Table1. Characteristics of the water erosion risk weighting.

\begin{tabular}{lll}
\hline $\begin{array}{l}\text { Risk of water } \\
\text { erosion }\end{array}$ & $\begin{array}{l}\text { Loss rate } \\
\text { (t/ha/yr) }\end{array}$ & \multicolumn{1}{c}{ Characteristics } \\
\hline 1 & 0 to 20 & $\begin{array}{l}\text {-Loss rate that is less than or near to the tolerance level: } \\
\text { soils on moderate slopes; surface erosion; shallower claws; } \\
\text { stripping with bright patches, soil well covered by flora; } \\
\text { soil protected by stepping stones; agricultural activities. }\end{array}$ \\
\hline \multirow{2}{*}{20 to 100} & $\begin{array}{l}\text { The loss rate is a concern: evidenterosion; bare soil on steep } \\
\text { slopes; bare and badly degraded soil; gullies and ravines; } \\
\text { extensive gullying; skeletal soil on rocky outcrops; deserted } \\
\text { stockyards; sparse vegetation. }\end{array}$ \\
\hline 3 & $\begin{array}{l}\text { - An alarming loss rate necessitates immediate intervention: } \\
\text { extremely severe deterioration; weak rocks on rocky } \\
\text { slopes; deep gullies; landslides and mass movement; } \\
\text { mudslides, bank undercutting, and Badlands; loss of } \\
\text { agricultural production. }\end{array}$ \\
\hline
\end{tabular}

[13] reported that the success rate of development strategies varies by territory. Under the NABVP, 1.5 Million hectares of managed soils have failed to stop erosion.

\subsection{Survey data analysis}

All of the 30 farmers and residents interviewed practice agricultural and animal husbandry. $13 \%$ depend on beekeeping, mainly in the Ida-Ou-Tanane and Anzerki plateaus. The average age of the interviewes farmers is 43 years. They are all active. 7 of the 30 residents are herders under the age of $20.63 .33 \%$ are illiterate, and $36.66 \%$ have only a secondary degree of education. Agroforestry is practiced by all of the farmers in the basin who were interviewed.Growing somewhat demanding fruit trees like olives, almonds, figs, pomegranate, and date palms helped to consolidate and maintain the soil. Grass (barley, wheat, and corn), legumes (fava beans, peas, lentils, and beans), and forage crops, particularly alfalfa (Medicago sativa), are all annual crops. Erosion is a severe concern for agricultural management and crops in the area, according to interview responses. Individual plots and farming locations were handled following local customs. Various structures and techniques of development and control of water erosion risk, particularly the building of terraces, banks, dikes, and bunds, are part of cultural heritage competence. However, management is generally collective and applied by all residents. Farmers in such situations use traditional technical skills on a small scale, with relative independence from local authorities. Almost all interviewees stressed the need to replenish what they loosely called small hill dams (SED), created by land dams for surface water supply and groundwater recharge to ensure water use by the rural people in future seasons. 


\subsection{Proposed support practice}

According to the final erosion map, regions of high and very high soil loss encompass around $48 \%$ of the basin's surface. When significant soil loss regions are included, more than half of the entire area, $54 \%$, comprises degraded soil. This vast region contains practically all of the basin's habitats and bioclimates. As a result, it provides a chance to diversify management strategies and plant species for reforestation. The list of advancements to be proposed is extensive and diverse. However, the most appropriate, practical, and cost-efficient methods for the terrain must be chosen. To preserve the basin's soils against water erosion, two types of interventions are recommended (Fig. 4 \& 5).

- Technical measures: contour ridge benches, contour ridge, and concrete or gabion sills.

- Biological measures (revegetation): Argan tree, Berber Thuja, Phoenicean Juniper, Olive tree, Carob, Fig tree and Alfalfa.
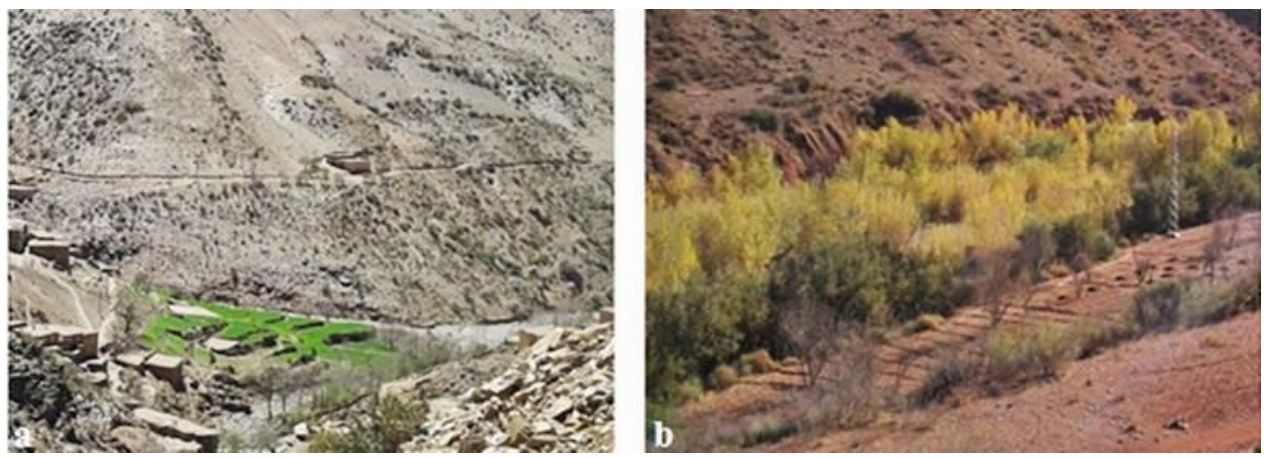

Fig.4. Irrigated terraces supported by dry stone walls following the contour lines near the rural commune of Imlmaiss, enclosed in the WHA (Photo a). View of ridges and bunds made only of soil and built exclusively by hand on market gardening plots, with the aim of conducting water from one basin to another (Ait Bkhayr valley) (Photo b).

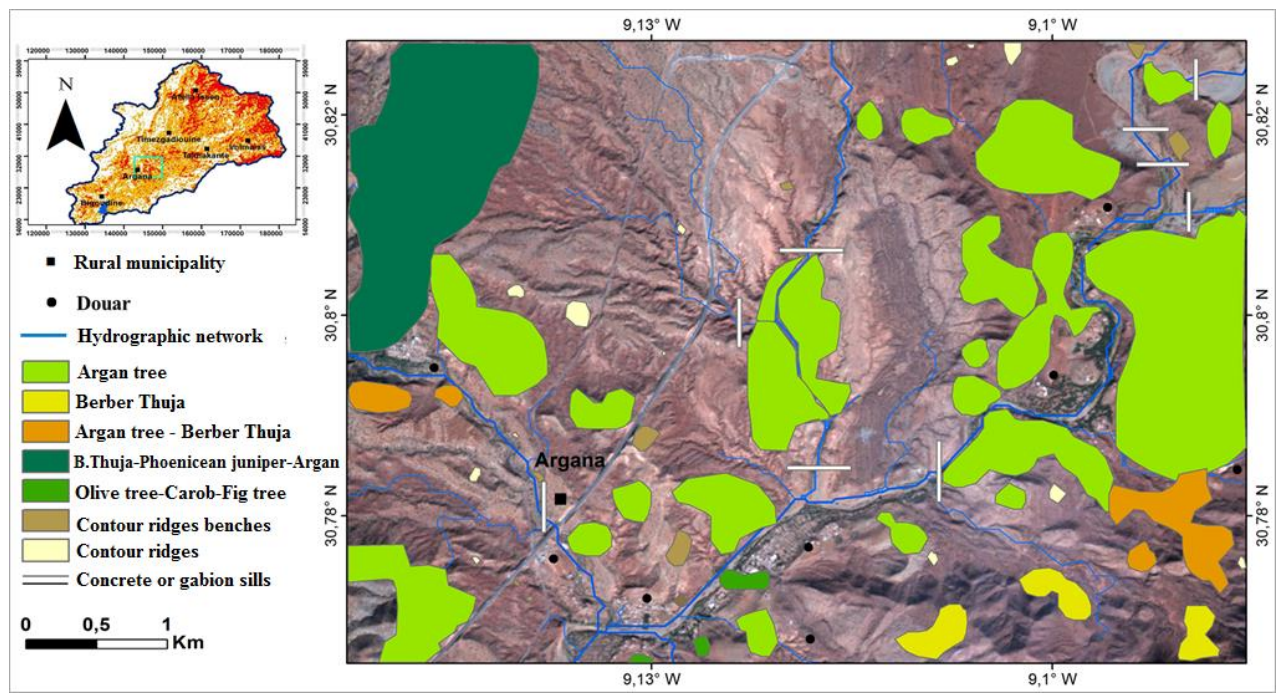

Fig.5. Simulation of the erosion control practices for the Argana site. 


\section{Conclusions}

Direct observations in the Argana basin and indirect views using Google Earth images have indicated that the soils are already degraded. The areas are barren in the bio-geographical sectors most important for development.They are quickly destroyed by fluvio-torrential erosion because they are composed mainly of clay-detritus formations that are sensitive to water erosion, compaction, suffusion, and solifluction.

Erosion control cannot be restricted to the maintenance of existing soils; it must also address soil productivity restauration by enhancing slope water management and soil physical characteristics.

The anticipated management strategy must encompass the whole basin, not only the sections threatened by very high or high soil erosion risk. It should encompass other regions, such as forests and rangelands, to increase pastoral output. These industries are likewise deeply worried about a potential intervention for soil and water conservation. Further, farmers' water and land management accomplishments should not be overlooked, particularly in the mountains. Only a meeting of a watershed's intervening agents, as well as integrated water and soil management strategy, can currently lessen the detrimental effects of water erosion and successfully combat it.

It enables the inclusion of soil erosion rate as a decision-making criterion in the land use planning process, notably in its integrated management.

More persistent monitoring of farmers is required to mobilize and instruct them on the many procedures and circumstances to consider when selecting acceptable species for planting and reforestation initiatives. This observation is common in most of the High Atlas's surrounding watersheds.In any way, the situation remains serious, given the acceleration of deforestation consequences and the limited resources of conservation measures.

As a response, it provided foundation for delivering a set of possible soil and water conservation activities and building a local development plan for erosion risk management.

\section{References}

1. W. Maetens, J. Poesen, M. Vanmaercke, Earth-Sci. Rev 115(1-2), 21-36 (2012b) https://doi.org/10.1016/j.earscirev.2012.08.003

2. J. M. García-Ruiz, S. Beguería, N. Lana-Renault, E. Nadal-Romero, A. Cerdà, Land Degrad Dev, 28(1), 5-21. (2017) https://doi.org/10.1002/ldr.2641

3. Y. Ostovari, A.A. Moosavi, H.R. Pourghasemi, Land Degrad Dev 31,15 1-12. (2020) https://doi.org/10.1002/ldr.3597

4. L. Croitoru, M. Sarraf, Environ. Nat. Resour. Global Practice Discussion Paper. 5. World Bank Group Report Number 105633-M (2017).

5. M. Ait Haddou, B. Kabbachi, A. Labbaci, S. Ezaidi, Y. Bouchriti, Int. J. Sci. Res. Innov. Std., 2,1 (2020a) https://ijarimss.org/publications/volume2-issue1/

6. M. Ait Haddou, B. Kabbachi, A. Aydda, H. Gougueni, Y. Bouchriti, E3S Web Conf. 183, 02003. (2020b) https://doi.org/10.1051/e3sconf/202018302003

7. A. Elmouden, N. Alahiane, M. El Faskaoui, Z.E.A. El Morjani,. In :Choukr-Allah R., Ragab R., Bouchaou L., Barceló D. (eds) The Souss-Massa River Basin, Morocco. Handb. Environ. Chem., 53 (2016) https://doi.org/10.1007/698_2016_70

8. É. Roose, M. Sabir, et A. Laouina, Gestion durable des eaux et des sols au Maroc: Valorisation des techniques traditionnelles méditerranéennes. Marseille : IRD Éditions, 343 p. (2010) https://doi.org/10.4000/books.irdeditions.294 
9. C. Ancey, Notes de cours : Risques hydrologiques et aménagement du territoire, Laboratoire Hydraulique Environnementale, Ecole Polytechnique fédérale de Lousanne (EPFL). Version 13.1 du 11 septembre, Lausanne, Suisse (2018) http://he.epfl.ch/hydrologie.php

10. K. G. Renard, A guide to conservation planning with the Revised Universal Soil Loss Equation (RUSLE) in Predicting soil erosion by water, DC : USDA, Washington, USA (1997)

11. A. Labbaci, S. Moukrim, S. Lahssini, S. Laaribya, H.M. Alaoui, J. Hallam, Adv. Sci. Technol. and Eng. Syst. J., vol. 6, no. 3, pp. 241-247 (2021) https://doi.org/10.25046/aj060326

12. I. Gaubi, A. Chaabani, A. B. Mammou, \& M. H. Hamza, Nat Hazards 86, 219-239 (2017) https://doi.org/10.1007/s11069-016-2684-3

13. A. Laouina, Peut-on attenuer les risques hydriques dans les piemonts atlasiques? Actes du colloque «Colloque International sur les risques naturels et l'aménagement du territoire». 9 et 10 novembre 2018, Oujda, Maroc (2018), Publications de l'Université Mohamed Ier, mis en ligne le 5 juillet 2019. http://www.ump.ma/ 